\title{
SOCIAL SUPPORT NETWORKS FOR WOMEN IN SITUATIONS OF VIOLENCE BY AN INTIMATE PARTNER
}

\author{
Leônidas de Albuquerque Netto', Maria Aparecida Vasconcelos Moura², Carla Luzia França Araujo, \\ Maria Helena do Nascimento Souza3, Giuliana Fernandes e Silva
}

${ }^{1}$ Ph.D. student in Programa de Pós-Graduação em Enfermagem, Escola de Enfermagem Anna Nery (EEAN), Universidade Federal do Rio de Janeiro (UFRJ). Rio de Janeiro, Rio de Janeiro, Brazil. E-mail: leonidasalbuquerque@bol.com.br

2 Ph.D. in Nursing. Professor, Departamento de Enfermagem Materno-Infantil, EEAN/UFRJ. Rio de Janeiro, Rio de Janeiro, Brazil. E-mail: maparecidavas@yahoo.com.br

${ }^{3}$ Ph.D. in Nursing. Professor, Departamento de Enfermagem Materno-Infantil, EEAN/UFRJ. Rio de Janeiro, Rio de Janeiro, Brazil. E-mail: araujo.ufrj@gmail.com

${ }^{4}$ Ph.D. in Nursing. Professor, Departamento de Enfermagem e Saúde Coletiva, EEAN/UFRJ. Rio de Janeiro, Rio de Janeiro, Brazil. E-mail: mhnsouza@yahoo.com.br

${ }^{5}$ Ph.D. student in Programa de Pós-Graduação em Enfermagem, EEAN/UFRJ. Rio de Janeiro, Rio de Janeiro, Brazil. E-mail: giulianafernandes@hotmail.com

\begin{abstract}
Objective: to analyze social network and types of support for women in situations of violence by an intimate partner.

Method: qualitative and analytical research, anchored in the Sanicola Social Network Theory. The social actors were 20 women who experienced partner violence who were interviewed at a Specialized Care Center in Rio de Janeiro, Brazil. A semi-structured and individual instrument was used. In order to elaborate a map of the social network, the women were asked to help the researcher in the production of a representative drawing of their relations with people and institutions in the context of violence. The theoretical approach allowed an understanding of the social relational dynamics faced by which women regarding violence. The statements were organized by the content analysis method.

Results: the primary social network of women was composed of children, siblings, sons-in-law, daughters-in-law and friends who provided emotional and material support. The secondary network was represented by the services and information support obtained in the hospital, health center, specialized care center and police station. The women had greater proximity and stronger bonds with children, daughtersin-law and sons-in-law; kept distance from their parents and had conflicting bonds in their relationship with the intimate partner.

Conclusion: discontinuous or fragile bonds for the most part, were identified with elements of the primary network; and the normal or strong, with the secondary network. Women are distant from the members of the primary network and close to the secondary network, establishing bonds through welcoming and resolute attention. The social network map built with women was determinant for support intervention for self-esteem.
\end{abstract}

DESCRIPTORS: Nursing. Women's health. Violence against women. Qualitative research. Social network

\section{AS REDES SOCIAIS DE APOIO ÀS MULHERES EM SITUAÇÃO DE VIOLÊNCIA PELO PARCEIRO ÍNTIMO}

\section{RESUMO}

Objetivo: analisar rede social e tipos de apoio às mulheres em situação de violência pelo parceiro íntimo.

Método: pesquisa qualitativa e analítica, ancorada na Teoria de Rede Social de Sanicola. Os atores sociais foram 20 mulheres que vivenciaram violência pelo parceiro, entrevistadas em Centro Especializado de Atendimento no Rio de Janeiro, Brasil. Utilizou-se instrumento semiestruturado e individual. Para elaborar mapa da rede social solicitou-se às mulheres que auxiliassem o pesquisador na confecção do desenho representativo de suas relações com pessoas e instituições no contexto da violência. A abordagem teórica permitiu entendimento das dinâmicas relacionais sociais em que a mulher está inserida para enfrentamento da violência. Os depoimentos foram organizados pelo método de análise de conteúdo.

Resultados: a rede social primária das mulheres foi composta por filhos, irmãos, genros, noras e amigos que prestaram apoio emocional e material. A rede secundária foi representada pelos serviços e apoio informativo obtidos no hospital, posto de saúde, centro especializado de atendimento e delegacia. As mulheres tiveram maior proximidade e vínculo forte com filhos, noras e genros; mantiveram distância dos pais e tiveram vínculos conflituosos na relação com o parceiro íntimo.

Conclusão: vínculos descontínuos ou frágeis, na maior parte, foram identificados com elementos da rede primária; e os normais ou fortes, com a rede secundária. As mulheres estão distantes dos membros da rede primária e próximas da rede secundária, estabelecendo vínculos pelo acolhimento e atenção resolutiva. O mapa de rede social construído com as mulheres foi determinante para intervenção de apoio para autoestima.

DESCRITORES: Enfermagem. Saúde da mulher. Violência contra a mulher. Pesquisa qualitativa. Rede social. 


\title{
LAS REDES SOCIALES DE APOYO A LAS MUJERES EN SITUACION DE VIOLENCIA POR SU COMPANERO INTIMO
}

\begin{abstract}
RESUMEN
Objetivo: analizar la red social y los tipos de apoyo a las mujeres en situación de violencia por el compañero íntimo.

Métodos: investigación cualitativa y analítica, anclada en la Teoría de Red Social de Sanicola. Los actores sociales fueron 20 mujeres que vivenciaron violencia por el compañero entrevistadas en un Centro Especializado de Atención en Rio de Janeiro, Brasil. Se utilizó un instrumento semi-estructurado e individual. Para elaborar el mapa de la red social se le solicitó a las mujeres que auxiliaran al investigador en la confección del diseño representativo de sus relaciones con personas e instituciones en el contexto de la violencia. El abordaje teórico permitió el entendimiento de las dinámicas relacionales sociales en que la mujer estuvo inmersa para el enfrentamiento de la violencia. Los discursos fueron organizados por el método de análisis de contenido.

Resultados: la red social primaria de las mujeres fue compuesto por hijos, hermanos, yernos, nueras y amigos que prestaron apoyo emocional y material. La red secundaria fue representada por los servicios por los servicios y apoyo informativo obtenidos en el hospital, puesto de salud, centro especializado de atendimiento y delegaciones. Las mujeres tuvieron mayor proximidad y vinculo fuerte con los hijos, nueras y yernos; mantuvieron distancia de los padres y tuvieron vínculos conflictivos en la relación con el compañero íntimo.

Conclusión: vínculos descontinuos o frágiles, en la mayoría, fueron identificados con elementos de la red primaria; y los normales o fuertes, con la red secundaria. Las mujeres están distantes de los miembros de la red primaria y próximas de la red secundaria, estableciendo vínculos por la recepción y atención resolutiva. El mapa de la red social construido con las mujeres fue determinante para la intervención de apoyo para autoestima.
\end{abstract}

DESCRIPTORES: Enfermería. Salud de la mujer. Violencia contra la mujer. Investigación cualitativa. Red social.

\section{INTRODUCTION}

In modern society, violence against women committed by an intimate partner, physically, psychologically, sexually, morally and patrimonial way is considered a public health problem and a violation of human rights ${ }^{1}$. In Brazil, $26 \%$ to $34.5 \%$ of the female population experiences some type of violence from their intimate partners..$^{2-3}$ According to the Brazilian Institute of Geography and Statistics, ${ }^{4}$ the female population in Brazil is 100.5 million. It is estimated that 34.17 million Brazilian women are in a situation of violence.

Violence against women is established within a gender perspective, as a sociocultural construction. For women, passivity, fragility and submission are determined; for men, activity, strength and domination. The gender dimension is structured as a relationship of power, implying usurpation of the body of another, and it is generally configured between men and women, leading to violence. ${ }^{5} \mathrm{In}$ a historical perspective, in 1994, the Convention in Belém do Pará (Brazil) which focus on the prevention, punishment and eradication of violence, has brought advances in women's rights, including the elucidation that all women have the right to life and to physical, mental and moral integrity; personal freedom and security; not to be subjected to torture; equal protection before the law and simple and prompt recourses before the competent courts. ${ }^{6}$

Women who experience these aggressions attend health services, one of the places where they can seek help. These services must be prepared to deal with this situation. ${ }^{3}$ Health professionals recognize the importance of welcoming these women, but they feel powerless in the face of this problem. The lack of professional training also feeds the invisibility of violence to care services. ${ }^{7}$ Many professionals tend to solve the case in the individuality of care, without the articulation with other elements of social support networks, at a personal or institutional level. This stance can be understood as a harmful attitude, compromising the care of the woman. ${ }^{8}$

In 2008, Brazil instituted the National Policy to Combat Violence Against Women, founding actions to prevent, combat and confront the situation of violence against women. ${ }^{9}$ Among the main guidelines includes the conception of the coping and assistance network as a strategy to combat violence. The construction of this network of attention seeks to respond promptly and resolutely to the complexity of violence against women and the multidimensional nature of the problem. It covers many areas, such as health, education, public safety, social assistance and culture. In Rio de Janeiro, women's health care networks (Redes de atenção à saúde-RAS) are comprised of Reference Centers for Women's Care (Centro de Referências de atendimento à mulher-CEAMs), shelter houses, temporary shelters, Specialized Police Stations for Women (Delegacias Especializadas de atendimento à mulher-DEAMs), Institute Legal Counsel, Women's Defenders, Domestic Violence Judges, Women's Assistance Center, Secretary for Women's Policies and Health Services; all from the perspective of health care. ${ }^{9}$

In Brazil, Law no. 11,340, called Maria da Penha Law, provides measures regarding multidisciplinary assistance to women in situations of violence and the multidisciplinary care team. ${ }^{10}$ 
According to the law, it must be integrated by professionals in the psychosocial, legal and health areas, and must obtain articulated actions in a network for the protection and attention to women. In the health team, doctors and nurses care for physical injuries, performing tests for detection of sexually transmitted diseases, providing emergency contraception and abortions in accordance to the law. Psychologists provide care to the women's mental health, in view of psychological violence with the aim of recovering self-esteem. Social workers communicate with network members who can assist women in their search for emotional or financial independence, proposing actions to improve the living conditions of this population and encouraging the implementation of care projects. ${ }^{11-13}$

The networks are important as a strategy to strengthen women in situations of violence. A network is the articulated set of services, and due to violence being a complex problem that manifests itself in multiple forms, requires a wide range of options for assistance. The network may be broad, depending on the location, and consists of police, judicial, psychosocial and health care services. Most importantly, these care institutions work interdisciplinarily in care, sharing knowledge in a coordinated and reciprocal manner, and seeking solutions to this problem through group articulation. ${ }^{14}$

Thinking and acting in a network produces questions directed to the hierarchical structures, leading to displacements of power. Many social agents involved in serving women, while sensitive to the issue, do not actually formulate network thinking. In general, the organization of services is based on a concept of fragmented care of the situation of the women. Depending on the focus of the problem - police, legal, psychosocial or health - there is a service that proposes to deal with the issue, but action, often does not foresee the establishment of effective network partnerships. ${ }^{15}$

The social network is understood as a set of interpersonal relationships that determine the characteristics of the person, such as: habits, customs, beliefs and values, and from this network, the person can receive support. ${ }^{16}$ The existence of ties with relatives, neighbors and institutions, such as church and community associations, is fundamental in helping situations of illness and difficulty. Social support networks can be responsible for the assistance, visibility of problems and satisfaction of social and health needs that escape the State's capacity for care. ${ }^{17}$

Social networks are considered a network of relationships that give each subject an identity and sense of belonging. The structure is formed by perceptible bonds that are established between people, organizations or institutions connected by some type of relationship. These loops, when triggered, generate connections that shape the network. This is defined as a set of interpersonal and social relationships in which the person can receive emotional, material, service or information support. Social support networks can be of a primary and secondary nature and are differentiated by the types of exchanges that take place between individuals, such as reciprocity, rights, money or a combination. ${ }^{16}$

In primary networks, bonds are characterized by relationships of kinship, friendship or neighborhood, based on reciprocity and trust. Secondary networks are formal or informal, and thr third sector, market or mixed. They differentiate themselves by the type of exchange: reciprocity, rights, money or a combination of these. The formal secondary network consists of official institutions, providing services according to the demands and exchange based on solidarity. The third sector of social networks are constituted by organizations providing services and exchanges based on law and solidarity. The social market network refers to economic activities, linked to money and to profit. ${ }^{16,18}$

In the development of this research, Sanicola's theoretical reference indicated instruments and resources necessary for theknowledge regarding the involvement of people and institutions in the relationship of women in situations of violence within the social support network. It also allowed deductions on the properties of the care network, with articulated and resolute interventions, in ceasing the violent relationship with the intimate partner. ${ }^{16}$

The knowledge about the social support network, in which the woman in a situation of violence perpetrated by the intimate partner is part of, facilitates the understanding of the relationship dynamics, aiding in the establishment of attention to health with the women. Therefore, the purpose of the study was to analyze the social network and the types of support provided to women in situations of intimate partner violence.

\section{METHOD}

A qualitative and analytical research, anchored in the theoretical-methodological framework of the Sanicola Social Network, ${ }^{16}$ developed in the CEAM of the city of Rio de Janeiro (Brazil). This is a Center managed by the Special Secretariat of Policies for Women of the City of Rio de Janeiro 
(SPM-Rio), guaranteeing actions for public policies, with the purpose of gender equality and the valorization of women. It acts to defend the rights of the female population and the inclusion of these women in the city's economy. ${ }^{19}$ In CEAM, women find support, guidance and specialized assistance in cases of physical, psychological, patrimonial, moral or sexual violence, in addition to social follow up and legal guidance and in the case of risk of death, a referral to a sheltering unit is made.

The participants in the study were those who experienced physical, psychological, sexual, moral or patrimonial violence. As an inclusion criterion, they must be over 18 years of age, having experienced any forms of violence, exclusive or overlapping, inflicted by the former or current husband, boyfriend or intimate partner, regardless of formal union or cohabitation. Exclusion criteria refer to those women with psychiatric disorders who would not be able to respond at the time of the interviews.

The researcher joined the team of professionals, by participating in the meetings and movements carried out by the CEAM, which allowed the sharing of activities with professionals in the field, allowing for a greater interaction and better articulation with the women assisted in this center. They were spoken to by the psychologist after consultation and informed about the purpose of the research and the anonymity of the participants. The information was collected only after the consent of the deponents and was only obtained in primary sources, direct, originating from the discourse of women in situations of violence by the intimate partner.

The interview was conducted individually, with a semi-structured instrument, concomitant with the design of the map of the social support networks, to understand the meaning attributed by women to the network elements. The average duration was approximately 50 minutes. Among the 61 women interviewed in the CEAM during the study period (September to December 2014), 20 were interviewed, according to the criterion of theoretical saturation of the data, when the information presented redundancies. ${ }^{20}$

In the interviews, the sociodemographic profile of the women was investigated, characterizing age, color, schooling, occupation, income, neighborhood of residence and relationship with the (former) intimate partner. Obtaining the testimonies began with questions about the presence of the elements, proximity or distance, types of bonds and support to the woman. Each of the deponents described the people and institutions that were present in their life in the experience of violence. The network elements can be relatives, friends, neighbors, colleagues and institutions, such as police stations, reference centers, shelters, specialized courts, schools, hospitals and health centers.

During the interview, the researcher worked with the women to design the social network map and support, using a notebook and the PowerPoint program, which made the creation of the geometric figures and graphic paths possible; Stimulating them with the visual in different colors, referring to the elements of the network and types of support bonds.

The social network researchers seek to understand the connections in the relational scope of the individuals and institutions of the network, problematizing the social configuration from the statements of women. Theoretical foundations aid the analysis, such as the amplitude, that refers to the number of people present, allowing to assert whether a network is small, medium or large; and density, referring to the number of people who know each other. ${ }^{16}$ It was also possible to investigate the intensity of the social network, the relationship of proximity and distance between members and their physical proximity to women.

The statements were recorded on digital media with the consent of the participants and the interviews were transcribed in full, aiming for the reliability of the information. These resources were fundamental for the registration, construction and finalization of the maps, as well as the preservation of the details of the bonds in the social network. Subsequently, a single network map representing the characteristics of the research participants was created, establishing the social network of women in situations of violence by the intimate partner.

The discourses were organized by the content analysis method, ${ }^{21}$ and a floating reading of the transcribed interviews was carried out, followed by an in-depth reading of the material, from which lines were grouped that showed the support of the friends, the positive attendance of DEAM, the good service provided by CEAM, the participation of the health sector and the support of educational institutions. The interpretation of the information was based on Sanicola's Social Network Theory.

The study was approved by the Research Ethics Committee of the Anna Nery School of Nursing and the São Francisco de Assis Health Care Institute of the Federal University of Rio de Janeiro, under protocol 774.804 / 2014 and CAAE. 34849514.8.0000.5238. The research was conducted in accordance with the required ethical standards. 
To participate in the research, it was essential to sign the Informed Consent Term for women. The anonymity was guaranteed by the use of the letter " $E$ " (Interview) instead of the interviewee's name, followed by Arabic numerals in ascending order of the interview (E1 to E20).

\section{RESULTS}

In relation to profile, five women were between 25 and 34 years of age; Four, between 35 and 44 years of age; Nine, from 45 to 54; And two were more than 55 years of age. Color of the skin, 12 declared themselves white; Seven, brown skinned; and one, black. Six declared to have completed elementary education; Ten, high school; And four, completed higher education. Professionally, eight were cleaning assistants, self-employed, clerk, housekeeper, administrative secretary, domestic help, hairdresser and manicurist and received half a minimum wage. Another three were librarians, business managers and event organizers and received between three and four salaries. Regarding residence, eleven women came from the north, five from the center, two from the west and two from the south. As for the current marital situation, sixteen women affirmed separation from the former partner.

Most of the women participants also had between one and three children with the aggressor partner. The younger participants, from infancy to adolescence, experienced the most aggressive episodes together with their mothers, while young or adult children helped more from an emotional perspective, encouraging them to seek care or safety institutions in the secondary social network. Many of them also provided material support, with the availability of financial resources for the survival of their parents, or with accommodation at their home.

The network drawings of the women obtained during the interviews made it possible to draw a single social network map of support against the relational context of women in situations of violence, shown in figure 1.

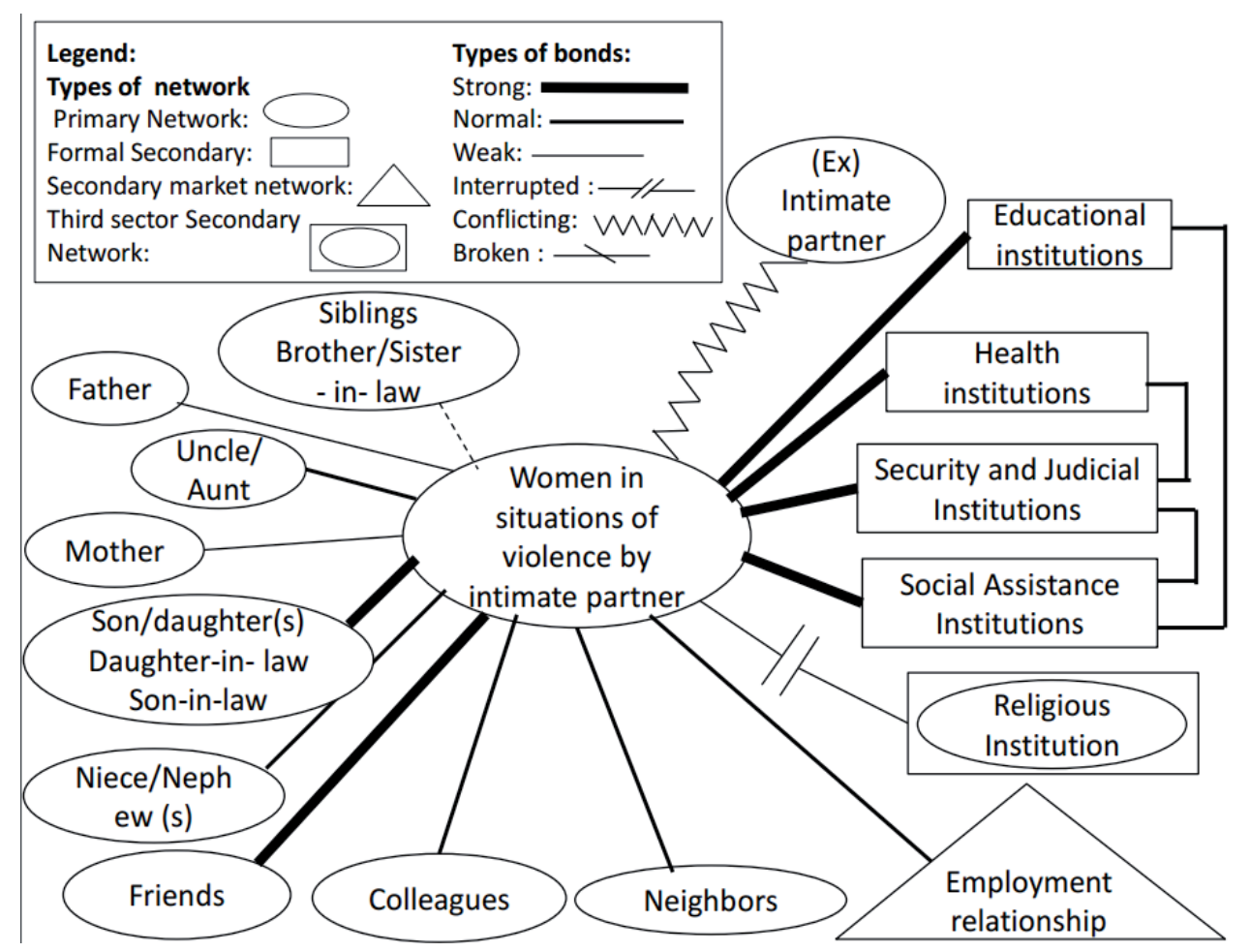

Figure 1 - Social network of the women participating in the study. Rio de Janeiro, RJ, Brazil, 2015.

The social network of women in situations of violence was of medium range (with 10 to 30 members), with whom they maintain a personal contact with in everyday life. However, the network is less dense among the elements of the primary network, such as relatives (siblings, sisters-in-law, brother-in-law, father, mother, uncles, aunts, sons, daughters, daughters-in-law, friends, colleagues and neighbors. These almost do not establish any relationships with each other, with few "nodes" in 
this scope of the social network. On the other hand, in the secondary network, at least the institutions of assistance, health, education and incarceration communicate with each other, demonstrating a greater density in this area of the social support network to women, which occurs mainly by reference and counter-reference among care services.

When studying the intensity of the social network, exchange relationships between women and network elements are indicated. The women participants had better exchange relationships of support with the secondary network. In the primary network, only their sons, daughters-in-law, sonsin-law and friends showed a strong bond, where they had emotional and material support. In the secondary social network, women have declared strong bonds with institutions of education, health, security, justice and social assistance, which have assisted them with availability and referrals to services or guidelines for escaping the cycle of violence.

The indicator of proximity and distance also reveals particularities and reflections on the social network of women. They had a degree of intimacy revealing closeness to their children, protecting them from violence, and familiarity with some siblings, from whom they asked for help in the face of violence. Some conditions of reservation were left to the parents, for whom, many times, they did not want to reveal the problem of the violence, avoiding bothering them, which worsened the social isolation of the deponents. Conflicting bonds were evident in the relationship of the woman with the aggressor partner.

As regards to the physical proximity between women and the elements of their social network, they are far from the members of their primary network and closer to the service centers and specialized police stations in the secondary network. Their relatives, friends, colleagues or neighbors often live far away, which also makes it difficult to find a helping relationship in the face of the vulnerability caused by violence. On the other hand, the elements of the secondary network, such as institutions, although not physically close to women, establish a strong bond with care and resolution assistance.

The members of the secondary network that assisted women in this same movement for their autonomy, self-esteem and empowerment were hospitals, health centers, specialized police stations, service centers and forums. Nurses, doctors, social workers, psychologists, lawyers and public defenders were highlighted in these establishments. These professionals became aware of the women and, concerned to help them recognized the elements of their social support network, helped them to find other people and institutions that could support them in other professional bodies.

Among women in situations of violence, in this study, their friends helped in the search for specialized care institutions, as verified in the following expressions: a friend searched the internet addresses that attend the needs of women, and it was she who told me that there was a CEAM; that's when I came here, where they helped me and suggested a vocational course (E4); A friend who told me about CEAM, she told me of this support center where they could guide me. She even called and asked if I could come (E7).

Ten of the women interviewed were guided by the DEAM and referred to the CEAM, advising them that they would have a specialized, attentive and resolute psychological care for the depressive situation in which many were found, as evidenced below: in DEAM I was well cared for, the professionals respected me and sent me to CEAM, the service is good here, they listen to us calmly (E9); The DEAM helped me with protection, and then sent me to the CEAM to follow up on my psychological and emotional care, here they treat us in a very human way (E14).

The deponents highlighted the reception and humanized care of the psychologists and social workers of the CEAM. This attitude led to the formation of strong bonds with the professionals of this institution, for the treatment offered and differentiated reception, as verified in the speeches: in CEAM, I am guided on what is best to do. Only here I can see a solution to my problem. Consultations with the psychologist are a comfort and they are good for me (E12); CEAM is a place that promises to help and support. In the police station and in the CEAM I was informed of my rights in the case of violence (E13).

In the face of women's attentive view and the formation of bonds with doctors, nurses and psychologists, they understood the origin of complaints and traumas of violence against women and they provided physical and structural health care and referred them to the CEAM, as examined in the statements: I came to CEAM, it was the health center that helped me, because it was there that I had prenatal care. They worry about me, they ask me if I'm eating well, because they know about the violence I experience (E1); The CEAM psychologist and the Family Clinic nurse were the ones who helped me the most. In the Clinic I received emotional care, information and also guidance (E2).

Education institutions were present to support women experiencing frailty caused by the intimate partner, as reported in the speeches: my son's school 
teacher gave me a mattress to sleep on. Every time there was soup at school, she would give me some to take home (E1); the teacher of my course supported me when she learned about my story, I told her that later after I didn't show up for the test, so she gave me another chance. At the end of the class she always asked if I was okay (E5).

\section{DISCUSSION}

In the social support network, there was a predominance of emotional, relationship, material and informative support, provided by some elements of the primary network among children, daughters-inlaw, sons-in-law and friends of women in situations of violence. The physical proximity of these network members, in relation to the study participants, provides a strong bond, being a support for many faced with the adversities imposed by the partner's violence.

Interpersonal relationships are presented as promoters of adaptation of people by providing social, emotional and informative support. Emotional support is provided through conversation and the establishment of affective relationships between people, while informative support relates to the guidance and information provided about community resources. ${ }^{22}$ According to social network theory, networks have many characteristics of families, groups and systems, but at the same time transcend them. ${ }^{16}$

Sanicola states that kinship, in the logic of belonging to the family, has as its most precious point of competence the care it offers its members. ${ }^{16}$ This capacity, based on the criterion of closeness, manifests itself when specific needs arise, such as emergency situations. These can manifest themselves when the woman no longer accepts the aggressions of the intimate partner and asks for help from people or institutions.

Most participants had at least one family member or relative, with whom they had a strong bond, who helped her in a material or emotional way. The main actions were donation of money or assets for subsistence, accommodation in the residence of relatives, and accompanying them to some institution of the secondary network for specialized care. The emotional support of these relatives was characterized by the dialogue for the maintenance of women's self-esteem, with an incentive to seek CEAM or DEAM to report the intimate partner.

While analyzing the family's assistance to the woman, this nucleus performs functions such as education, establishing the experience of socialization that allows the development of trust and col- laboration. Another function of the family is care, since it assumes the needs of its components and the most fragile members, mobilizes the solidarity of the primary networks and activates the secondary networks. The transaction occurs from within the family to the networks, when it opens to the social dimension, transmitting and receiving resources and skills. The protection function comes in such a way as to defend its members, having purpose as the common good.

The number of friends in the primary social network varied. Ten women reported the presence of only one to three, who helped them emotionally, defending their autonomy and encouraging them to search for professional support. Two women reported not having friends in their social network. The network of friendships establishes a network of specific and qualitatively unmistakable relationships, which can create support, forming dynamics of solidarity of great collective breath. The more a person ages, the smaller the number of friends there are in their network. This is determined by two cultural factors: the way work becomes a reality of all interests, in which relationships occurs in the professional scope; and family life as a scope that encompasses the expectations, desires and possibilities of a family life. ${ }^{16}$

Violence against women promotes a significant emotional imbalance between the working life and the family. The recurrent aggressive acts of the intimate partner jeopardize the social relationships of women in the place where they work, and also in the relationship with relatives, especially the children, who sometimes experience violence in the family nucleus; and who are often the most disadvantaged, because of the woman's own emotional imbalance caused by violence.

Children are important members of women's social network, with whom practically all of them maintain a strong bond, regardless of age or cohabitation. They worry about the integrity and health of these young people who, in some cases, also experienced violence from their father. In particular, older children are those who emotionally support mothers, comforting them in the moments after the assaults, or even advising them to seek out a specialized center. Faced with maternal feelings of protection, as well as the need to provide a healthy family environment for the children, women feel the need to confront and break the cycle of violence. ${ }^{23-24}$

Primary social networks are generated over time, and cannot be created or reproduced, because their configuration is strongly linked to the freedom 
of choice of individuals and even to the collectives that establish them. But they can be promoted, moved and oriented, in the way they are identified, recognized and valued. Networks establish the cultural pole of social reality, the framework in which the values essential to the life of individuals are generated and learned, which will be assumed as a fundamental reference point for the guidance and action of a person in society. ${ }^{16}$

Among the women participating in the study, the experience of violence greatly influenced their selection and evaluation of who is or is not part of their primary social network. The configuration of this network can be modified over time, also by the intimate partner's violence. At the time of the interview, the participants were free to choose and define individuals and established bonds, which varied mainly according to the support received or even the different reactions to the science of aggressive acts to that woman. Sometimes there is still a naturalization of the violence by relatives and friends who tend to blame them for the aggressive acts of the partners.

When women do not have the support of the primary network, they resort to secondary network institutions, sometimes alone, as 14 women reported in this study. Regarding this movement, the method developed by the network intervention postulates that the primary networks - the family, in the first place - must establish a relation of autonomy with the secondary networks, which, in turn, must provide help without replacing the primary networks and expropriating them of their potential for social protagonism. ${ }^{16}$

Among the formal secondary networks characterized by the exchange of rights, 16 women in situations of violence resorted to DEAM as an institution of refuge. This was the first place where the majority sought care, which included their protection and that of their children. The punishment of the intimate partners was not a priority for this female population, at least at that time. The search for a safe place was considered as a necessity for these women as they sought out the specialized police station. This was another of the organized assistance services in which informative and service support for women was predominated. They received instructions regarding their rights in justice and citizenship, they reported the violence in the police records as well as the forms of punishment which would befall the intimate partners.

Some scholars draw attention to the misconception about the perception of violence against women as a problem only for the police, since the various professionals in areas such as health and social work restrict their professional conduct to the referral of women to the police station. The perception of many professionals is that reporting is the only instrument of resolution for violence. ${ }^{25}$ In fact, this is a paradigm that does not reflect the socio-historical-cultural phenomenon of violence, considering its repercussions in the different areas of knowledge in social, political and legal sciences, as a practice of the implementation of public policies.

The institutions of reference in social assistance and psychology were also very present in the process of attention to the emotional picture and restoring the self-esteem of these women. This support came mainly through the action of CEAM, where they had specialized support to maintain or rescue their autonomy. The deponents highlighted the differentiated reception and the humanized care of psychologists and social workers, which provided the formation of strong ties with this institution.

In this context, the conditions of violence demonstrated the importance of a comprehensive, integrated and effective social network of inter-sectoral support in the attention to women's health. ${ }^{26}$ These should be composed of at least, shelters, rehabilitation centers, and police stations for woman. Relevant profiles can be assumed to enable the integrality and effectiveness of the service to women.

Among the 20 women interviewed, only seven sought health institutions faced with the consequences of violence, where Basic Health Units, Family Clinics and Emergency Care Units predominated as elements of social support networks. The first two were scenarios sought by women when reporting multiple complaints, but without revealing partner violence. The lack of te perception of violence in the intimate relationship as an object of the health area ends up making women even more vulnerable, leading them to becoming ill by experiencing a daily life of disrespectful actions. Not feeling welcomed by health professionals and determined not to make the complaint, they remain silent. The articulation of the health area as a form of organization with other services, such as security and justice, is reported by many nurses and physicians as an indispensable strategy for coping with violence against women..$^{27-28}$

Only four women had the help of educational institutions, but with strong bonds. Two stated that the teachers helped them with re-checking evidence when they learned of the violence. Another received material support from the school where the son studies, when the teacher helped with food. Both 
the school and all elements of the formal secondary network are founded on the reciprocity, rights, money or combination of all of these means. They act on the principle of equality, with exchanges based on law or citizenship and use redistribution as a method and law as a means. One of the main criteria is enforceability, and can be demanded by the users. These networks are financed by the contribution system, providing services or granting aid. ${ }^{16}$

The elements belonging to the secondary networks of the third sector were churches, in which 18 women declared to have religion, being eight with an interrupted bond. They claimed that they did not go to church for fear of repression or disapproval of religious leaders, because they desired separation from the partner. Third-sector secondary networks take an intermediate position between the informal and the formal; even if they do not belong to primary relations, are culturally close, for they are animated for giving and interpreting the needs of the community. They are evidenced by reciprocity and exchange of law and solidarity and provide non-profit services. ${ }^{16}$

Most of the women interviewed (12) were employed and had their own income, albeit low, which characterized the stable relationship with their secondary market network. Another nine respondents stated that they felt good about their paid activities by establishing normal or strong bonds, while three women were not satisfied with their roles, either because of low financial returns or because of the excessive fatigue experienced in a double work load between working out of the home and performing household chores and activities.

A survey carried out in Spain on intimate partner violence has shown employment in the labor market as a protection factor against violence..$^{29}$ This research investigated women who sought support in the CEAM, and the fact that they were working was a deciding factor in the termination of the relationship with the partner, considering that the market network uses money as the medium. In this sense, there is the possibility of leaving the job, having links in relation to what is changed, in what can be professionally developed. These networks belong to the economic sphere, and are based on equivalence and use as the market as a method to buy and sell.

\section{CONCLUSION}

Women in intimate partner violence presented a vulnerable sociodemographic profile. The age group corresponding to the climacteric phase consisted of the majority of women between 45 and 55 years of age, they were white and had a complete average level of schooling. They worked in low-paying jobs, receiving minimum wage and resided in neighborhoods near a CEAM. As for the relationship with the intimate partner, most of the women had separated from the aggressors.

The social support network of women was of medium amplitude, with low density in the primary network and higher density in the secondary network, where the elements established interactions with each other. There were better relations of exchange between institutions of education, health, security, justice and social assistance. From the primary social network, women had emotional and material support from their children, daughtersin-law, sons-in-law and friends, with strong ties. On the other hand, the secondary network assisted with assistance services or providing information to the woman, developing strong links with schools, health posts, DEAMs and CEAMs.

Women showed closeness to their children, protecting them from violence; as well as familiarity with siblings, from whom they requested help. Many did not reveal the violence to their parents, aggravating their isolation. Conflicting bonds were evidenced in the relationship with the (ex) intimate partner. Women are far from the primary network and closer to the secondary network, where they establish a strong bond. In the minor third-sector networks, they declared an interrupted bond with the church, for fear of disapproving the end of the marital relationship. The majority had a normal bond with the secondary market network, considering the important work for their subsistence and autonomy.

The construction of the social network map of these women has an influence, first, on their perception that there are always people or institutions that can provide them support, even if they are scarce. As much as they feel isolated and dependent faced with fragility and vulnerability caused by partner violence, there is always hope that the process of building the social network map will provide a recognition of the main active elements in helping women. When health professionals, including nurses, attend women suspected victims of violence, they carry out anamnesis and nursing history. This standardized information will help identify real or potential health problems that can lead to the identification of evidence or evidence of violence. The construction of the social network support map is a proposal of improvement so that nurses can act in the integration of resources, as coordinators of the hypotheses of solution of violence. This network should be es- 
tablished and articulated to rescue the woman from the vulnerability of the situation of violence. Health professionals should accompany it with the social network, helping to maintain links favorable to the conservation of self-esteem and integrity. Social assistance and security agencies can be activated by contacting DEAM, CEAM or sheltering units, and contributing with integral care, trying to keep the woman out of the violent relationship.

The social network support map can be a first step towards an articulate and resolute intervention to recover women's self-esteem. By recognizing their inclusion in a dynamic social network, with different people and institutions, they have the possibility to organize their attitudes in decision making, resorting to those elements with the best conditions to assist them in face of their experienced problems.

The limitation of the research occurred due to the development in only one scenario - CEAM, because the diversity of the scenarios is essential to broaden the discussions of the theme. The development of the study was a challenge due to the thematic approach of violence among women, sensitized by the approach of experiencing the problem in the search for self-esteem, autonomy and the breaking of the cycle of violence, reaffirming the contribution of the social support network. Dissemination of the formal secondary social network elements among health professionals who attend to women in situations of violence is recommended.

\section{REFERÊNCIAS}

1. World Health Organization (WHO), Clinical and Policy Guideline. Responding to intimate partner violence and sexual violence against women. WHO; 2013.

2. Miranda MPM, Paula CS, Bordin IA. Violência conjugal física contra a mulher na vida: prevalência e impacto imediato na saúde, trabalho e família. Rev Paname Salud Publica. 2010 Abr; 27(4): 300-8.

3. Vieira EM, Perdona GSC, Santos MA. Factors associated with intimate partner physical violence among health service users. Rev Saúde Pública. 2011 Ago; 45(4):730-7.

4. Instituto Brasileiro de Geografia e Estatística (IBGE) [Internet]. Pesquisa Nacional de Amostra por Domicílios de 2010 [cited 2015 May 22]. Available from: http://www.ibge.gov.br/home/estatistica/ pesquisas/pesquisa_resultados.php?id_pesquisa $=40$

5. Ministério da Saúde (BR). Prevenção e Tratamento dos Agravos Resultantes da Violência Sexual Contra Mulheres e Adolescentes. Norma Técnica. $3^{\mathrm{a}}$ ed. Série A. Normas e Manuais Técnicos. Série Direitos Sexuais e Direitos Reprodutivos - Caderno n ${ }^{\circ}$ 6. Brasília (DF): 2012.
6. Organização dos Estados Americanos. Convenção interamericana para prevenir, punir e erradicar a violência contra violência [Internet]. Belém do Pará. 1994 [cited 2016 Jul 18]. Available from: https:// www.cidh.oas.org/basicos/portugues/m.Belem. do.Para.htm

7. Guedes RN, Fonseca RMGS, Egry EY. The evaluative limits and possibilities in the Family Health Strategy for gender-based violence. Rev Esc Enferm USP. 2013 Abr; 47(2):304-11.

8. Pedrosa CM, Spink MJP. A violência contra mulher no cotidiano dos serviços de saúde: desafios para a formação médica. Saúde soc. 2011 Jan-Mar; 20(1):124-35.

9. Presidência da República (BR). Secretaria de Políticas para as Mulheres. Coleção Enfrentamento à Violência Contra as Mulheres. Política Nacional de Enfrentamento à Violência contra as Mulheres. Brasília (DF); 2008.

10. Brasil. Lei $n^{\circ} 11.340$, de 7 de agosto de 2006. Lei Maria da Penha. Diário Oficial União, 8 ago. 2006.

11. Oliveira AFPL, Schraiber LB. Mulheres em situação de violência: entre rotas críticas e redes intersetoriais de atenção. Rev Medicina. 2013; 92(2):134-40.

12. Garbin CAS. Recognition and reporting of violence by professionals of the family health strategy. Arch Health Invest. 2016; 5(1):8-12.

13. Silva EB, Padoin SMM, Vianna LAC. Violence against women and care practice in the health professional. Texto Contexto Enferm [Internet]. 2015 [cited 2016 Jul 18]; 24(1):229-37. Available from: http:/ / www.scielo.br/scielo.php?script=sci_ abstract\&pid=S0104-07072015000100229\&lng=pt\&n $\mathrm{rm}=\mathrm{iso} \& \operatorname{lng}=\mathrm{en}$

14. Schraiber LB, Barros CRS, Castilho EA. Violence against women by intimate partners: use of health services. Rev Bras Epidemiol. 2010; 13(2):237-45.

15. Santos MA, Vieira EM. Social resources to support women living in situation of violence in Ribeirão Preto, SP, in the perspective of key informants. Interface Comunic Saúde Educ. 2011 Jan-Mar; 15(36):93-108.

16. Sanicola, L. As dinâmicas da rede e o trabalho social. São Paulo: Veras; 2008.

17. Ruiz ENF, Gerhardt TE. Public policies in rural areas: visibility and social participation as perspectives of supportive citizenship and health. Physis Rev Saúde Coletiva. 2012; 22(3):1191-209.

18. Souza MHN, Souza IEO, Tocantins FR. The use of social network methodological framework in nursing care to breastfeeding women. Rev Latino-Am Enfermagem. 2009 Mai-Jun; 17(3):70-6.

19. Secretaria Especial de Políticas para as Mulheres [Internet]. Rio de Janeiro. [cited 2014 May 15]; Available from: http://www.rio.rj.gov.br/web/spmrio/conheca-a-secretaria 
20. Fontanella BJB, Ricas J, Turato ER. Amostragem por saturação em pesquisas qualitativas em saúde: contribuições teóricas. Cad Saúde Pública. 2008 Jan; 24(1):17-27.

21. Bardin L. Análise de conteúdo. São Paulo: Edições 70; 2011.

22. Carlos DM, Ferriani MGC, Esteves MR, Silva LMP, Scatena L. Social support from the perspective of adolescent victims of domestic violence. Rev Esc Enferm USP. 2014 Ago; 48 (4):610-7.

23. Trigueiro TH, Labronici LM, Merighi MAB, Raimondo ML. The process of resilience in women who are victims of domestic violence: a qualitative approach. Cogitare Enferm. 2014 Jul-Set; 19(3):437-43.

24. Ferraz MIR, Labronici LM. Fragments of female corporeality in victims of domestic violence: a phenomenological approach. Texto Contexto Enferm [Internet]. 2015 [cited 2016 Jul 18]; 24(3):842-9. Available from: http:/ / www.scielo.br/scielo.php?script=sci_ arttext\&pid=S0104-07072015000300842

25. Gomes NP, Silveira YM, Diniz NMF, Paixão GPN, Camargo CL, Gomes NR. Identification of violence in the conjugal relationship based on the Family Health Strategy. Texto Contexto Enferm [Internet].
2013 Jul-Set [cited 2016 Jul 18]; 22(3):789-96. Available from: http:/ / www.scielo.br/scielo.php?pid=S010407072013000300027\&script=sci_arttext\&tlng=en

26. Oliveira MT, Samico I, Ishigami ABM, Nascimento RMM. Intra-family violence: health workers' practice in São Joaquim do Monte, Pernambuco, Brazil. Rev Bras Epidemiol. 2012 Mar; 15(1):166-78.

27. Gomes NP, Bonfim ANA, Barros RD, Silva Filho CC, Diniz NMF. Confronting domestic violence within the family health strategy. Rev Enferm UERJ. 2014 Jul-Ago; 22 (4):477-81.

28. Gomes NP, Diniz NMF, Reis LA, Erdmann AL. The social network for confronting conjugal violence: representations of women who experience this health issue. Texto Contexto Enferm [Internet]. 2015 [cited 2016 Jul 18]; 24(2):316-24. Available from: http://www.scielo.br/scielo.php?script=sci arttext\&pid=S0104-07072015000200316

29. Velasco C, Luna JD, Martin A, Caño A, Martin-de-lasHeras S. Intimate partner violence against Spanish pregnant women: application of two screening instruments to assess prevalence and associated factors. Acta Obstet Gynecol Scand. 2014 Out; 93(10):1050-8. 